\title{
THE AUSTERITY FUELLED WAVE OF CONTENTION IN CROATIA - MYTH OR REALITY?
}

\author{
Ana Balković \\ Universitat Autonoma de Barcelona, Spain \\ Faculty of Political Science \\ University of Zagreb \\ E-mail: ana.balkovic@fpzg.hr
}

DOI: 10.20901/an.16.04

Original scientific article

Accepted: December, 2019

\begin{abstract}
Analyses of protest dynamics in Croatia are rare, partially because until know it was not possible to view them systematically. Relying on the newly collected protest event data 2000-2017, this paper describes the main trends and dynamics of protest activities in Croatia in the observed period. It re-examines Beissinger and Sasse's claim about the absence of austerity related protests in Croatia after 2008. The analysis shows that though protests directly addressing austerity were relatively scarce, when the protest set is expanded to protests which demanded free public education, advocated labour rights, and fought for the right to the city, the prevailing thesis about "quietism" in Croatia can be challenged. The paper aims to relate some of the observed protest dynamics to Kerbo's distinction between movements of crisis and movements of affluence. Focusing on the period between the student movement in 2008 until Facebook protests in 2011, it shows that the student movement and "The Right to the City" movement preceded Facebook protests in formulating and expressing socio-economic grievances and articulated anti-systemic sentiment. Due to their strong organizational structure, resources and activists' "know-how", these movements resemble Kerbo's movements of affluence. On the other hand, the 2011 Facebook protests lacked organizational structure and continuous engagement and can be seen as movements of crisis.
\end{abstract}

Key Words Croatia, protest event analysis, protest dynamics, austerity protests

\section{Introduction}

Over the past decade, following the economic crisis of 2008, protest waves have been flowing the streets articulating citizens' discontent, opposing austerity measures, blaming national governments for political unresponsiveness, and calling for democratic renewal (Beissinger and Sasse 2014; Della Porta 2015; Grasso and Giugni 2016). Citi- zens' radical reactions were not directly prompted by crisis itself, but rather by governmental responses to the crisis as the implemented austerity measures only perpetuated economic uncertainty (Bermeo and Bartels 2014). Austerity measures imposed by the European Union (EU) to some of the member states and candidate countries served as a convergent external force which, once implemented in a particular country, led 
to different outcomes in terms of pace of economic recovery, socio-economic situation in general, but also to the specific political participation patterns at aggregate level (Della Porta 2017).

The scholars assumed that anti-austerity protests would be more frequent and bigger in size when compared to the protests in the age of relatively stable political and economic periods. It was expected that the protesters' demands would address specific austerity measures such as changes in employment legislation, social services, pensions and education (Cisar and Navratil 2016). Greek and Spanish, Portuguese, Icelandic, and even Italian and Irish experience confirmed these expectations (Vogiatzoglou, Romanos, Fernandes, Andretta and O'Connor 2017). However, when compared to each other, countries such as Spain or Greece have seen significantly stronger waves of contention than Portugal or Italy which introduced austerity measures as well. The scarce literature on the anti-austerity protests in Central and Eastern Europe (Beissinger and Sasse 2014; Cisar and Navratil 2016) came to a similar conclusion: no unique pattern of protest participation across the European countries hit by the crisis has been observed.

In the evening of December 5, 2008, approximately 10,000 people protested in different Croatian cities. ${ }^{1}$ Shouting "Tighten your belt, you gang of thieves" they were replying to the statement of the then Prime Minister, Ivo Sanader, who claimed that an economic crisis would not hit Croatia, but advised citizens to tighten their belts ${ }^{2}$ during the upcom-

https://www.jutarnji.hr/arhiva/prosvjednici-porucili-stegnite-vi-svoj-remen/ 3987987/

2 In Croatian, the expression "Stegnite remen" (tighten your belt) is used figuratively to advise someone to cut their spending to prevent financial difficulties. ing holiday season. ${ }^{3}$ When in autumn of 2012 the social-democrat government decided to cancel collective agreements in the public sector, the Prime Minister, Zoran Milanović, reminded citizens that the Government had made "some promises" towards the EU and that this decision was the only way to continue with fiscal consolidation. Only around 5,000 protesters rebelled against the introduced policy. That number seems marginal if noted that the said decision targeted benefits of over 180,000 public sector workers and, consequently, impacted their households. ${ }^{4}$ Based on similar newspaper reports, Croatia was described in the literature (Beissinger and Sasse 2014) as one of the most notable exceptions from the assumption that numerous and sizable anti-austerity protests were going to happen if a country went into recession. However, the Croatian cycle of anti-austerity protests has not been studied in depth. Beissinger and Sasse (2014) assume that Croatian citizens remained relatively calm and offered little to no resistance to the introduction of austerity measures but offer no conclusive answers to the question why an austerity-fuelled cycle of contention did not occur as it did elsewhere. This paper explores this question by analysing new data from 2000 to 2017 collected via protest event analysis (PEA hereafter) within the "Disobedient Democracy: A Comparative Analysis of Contentious Politics in European Semi-periphery" project. $^{5}$

3 https://www.24sata.hr/news/steze-remensanader-se-odrice-1300-kn-vece-place-88524

4 http://www.sssh.hr/hr/vise/nacionalne-aktivnosti-72/prosvjed-prosvjetara-i-medicinara-protiv-vladinih-mjera-stednje-90

5 "Disobedient Democracy" is a comparative research project exploring how protest politics advances democracy, implemented by the Faculty of Political Science of the University of Zagreb, financed by the Swiss National Science Foundation under the initiative "Promotion of Young Scientists in 
The contribution to the literature is twofold. First, it gives an extensive overview of protest activities in Croatia in the last two decades and shows that national varieties of capitalism influence patterns of protest participation in a given country. Second, by analysing protests in the period after the economic crisis, the paper shows that protests directly addressing specific austerity measures were indeed relatively scarce and reactive. However, when these events are linked to numerous other protests that demanded free public education, advocated labour rights, and fought for the right to the city - the notion of "quietism" dominating the mainstream political discourse can be challenged. Furthermore, the paper aims to relate some of the observed protest dynamics to Kerbo's (1982) distinction between movements of crisis and movements of affluence by focusing on the period between the student movement in 2008 until Facebook protests in 2011. The student movement and "The Right to the City" movement preceded Facebook protests in formulating and expressing socio-economic grievances and articulated anti-systemic sentiment. Due to their organizational structure and resources they resemble Kerbo's movements of affluence, while the 2011 Facebook protests lacked organizational structure and continuous engagement and, in that sense, can be seen as corresponding to movements of crisis.

This paper is structured as follows. As the data on protest activities in Croatia has not been collected thus far, the data collection and the method used for analysis are presented first. The paper is based on novel data, which is used to analyse the longitudinal evolution of protests, and to apprehend particular features of protest activity in the Croatian context. The following section presents

Eastern Europe" (PROMYS), and led by the principal investigator, Danijela Dolenec. theoretical explanations that link the phenomenon of protest participation to cycles of economic recession. After that it gives an overview of the political and economic context in Croatia from the early 1990s until the onset of the economic crisis. Finally, the results of PEA are discussed.

\section{Protest Event Analysis}

Data used in this paper has been collected via PEA within the "Disobedient Democracy" project. For the Croatian case, data has been gathered in late 2017 and 2018 at the Faculty of Political Science of the University of Zagreb. ${ }^{6}$

In the last three decades PEA has become one of the most important methods in social movement studies. The "eventful turn" (Tarrow 2012) in social sciences has brought the focus back to the event as a theoretically relevant concept. No matter the specific method or technique applied, qualitative or quantitative, PEA represents a helpful tool in systematic gathering and organization of the data and remains central to the study of protest mobilization (Hutter 2014; Koopmans and Rucht 2002).

PEA is a type of content analysis that assesses the features of protests across space and over time and is particularly useful for analysing the longitudinal evolution of protests. It easily identifies protest campaigns spanning over certain time periods and/or taking place at different locations (Hutter 2014). PEA helps to achieve historically and

6 The entire comparative dataset has been composed in 2019. It contains data collected during 2017 and 2018 for protest events in 2000 - 2017. Groups of researchers from the Faculty of Political Science of the University of Zagreb, Complutense University of Madrid, Nova University of Lisbon and Institute for Philosophy and Social Theory of the University of Belgrade collected data for Croatia, Spain, Portugal and Serbia respectively. 
comparatively relevant insights regarding social movement dynamics (Hutter 2014; Earl et al. 2004). As with almost any other method of social research, two main shortcomings stem from sources of bias in data collection (Tilly 2002 and Hutter 2014). First, the selection bias, meaning that the protest events reported in the news might not be representative of the amount of protests that took place in reality (Oliver and Maney 2000; Earl et al. 2004; Ortiz et al. 2005; Hutter 2014). Second, the description bias, meaning that for various reasons news reports can contain mistaken, imprecise or incomplete descriptions of an event (Ortiz et al. 2005; Tilly 2002).

The main objective of the data collection was to correctly identify all cases of protest events covered in the national daily newspapers selected for analysis, and to code the available information reported on each identified event. Newspaper items were used as factual sources meaning that PEA relies on newspaper data as an imperfect, but, in the scarcity of alternative sources apt for comparative research (Koopmans 1995 in Kriesi et al. 1995), the best available source of information. As other researchers working with the newspaper data, we are aware of the risk of selection in news coverage. However, it is assumed that the pattern of selection of reported events is relatively stable across time and issues, and that the number of reported events tracks real changes of protest activities in the population of actual events (Oliver and Maney 2000). Earl et al. (2004) identify three sets of factors predicting the selection bias: first, larger and more violent protests are more likely to be covered in the media; second, local and leftist newspapers are going to be less selective in covering protests than national and conservative ones; third, protests addressing issues of general relevance are more likely to be covered than those dealing with specific demands. To tackle the bias, but also to enable cross-country comparisons, two quality national daily newspapers of different ideological stance were used as data sources in each country. In the case of Croatia, Jutarnji list and Večernji list were used. To avoid additional selection, all editions from January $1^{\text {st }}, 2000$ until December $31^{\text {st }}$, 2017 have been used for the analysis. The coders performed traditional event coding since the selected newspapers are published in various languages, and since some of them never digitalized their archives. ${ }^{7}$ The coding consisted of two consecutive phases: first, the identification of protest events, and second, their classification based on selected attributes such as duration, type, organizers, participants etc. (Makarov et al. 2016). All coders were BA and MA students of political science and sociology with previous theoretical knowledge of contentious politics, native Croatian speakers with a professional command of English. The identification process was limited to events that took place within the selected country, and events that occurred in other countries and were reported on in national newspapers were not taken into account.

As the nature of protest events significantly varies, particularly across different national contexts, no strict definition of a protest event was provided to

The protocol for entering data on protest events was located online, at http://disdem.org, and could be accessed through an account. The interface directed the coders, reducing space for error. Coders were able to simultaneously input data, without having to save the local version of their dataset, which enabled them to have only one version of the dataset in every time point. Also, team leaders who supervised data collection and coding were able to review the data in real time. Given that data was collected simultaneously at several locations, these features of the protocol made it much more effective. 
the coders. The coders were instructed to identify all events that made political claims in public, on behalf of an individual or a collective. Also, a protest event was considered to be a meaningful unit, tied together by a shared objective, which means it could span across several locations and over time. To provide better guidance for the identification process, we listed different forms of protest strategies and methods, ranging from "traditional" protest strategies such as marches, demonstrations and strikes, to newer strategies e.g. acampadas. The list was adapted according to PEA codebooks from earlier studies. ${ }^{8}$

\section{Who Participates in the Austerity Fuelled Cycle of Contention and Why?}

What is known from the literature on protest participation, is mostly based on studies focusing on movements of affluence (Kerbo 1982) - usually and particularly - in "advanced democracies, with expanding welfare provisions" (Della Porta 2017: 262). These studies showed that the main preconditions for protest participation were political opportunities and an abundance of resources. Contrarily, Tarrow (1993) used Zolberg's (1972) phrase on "moments of madness - when all is possible" to introduce the idea that in times of crisis the possibility of mobilization increases because collective actions unfold when changing political opportunities enable the engagement of actors who lack resources on their own (Tarrow 2012). Therefore, two approaches are used to explain the preconditions for political

8 The list was designed according to PEA codebooks used in several recent research projects which aimed to gather PEA data. The DisDem research team gratefully acknowledges Grzegorz Ekiert and Jan Kubik, Mark Beissinger, and Martin Portos for providing us with unpublished codebooks they have composed. participation. One claims that resources matter for any mode of political participation, and consequently, for protest participation as well (Almond and Verba 1963; Verba and Nie 1972; Brady et al. 1995; Verba et al. 1995; Dalton 1988, 2008). On the other hand, grievances and discontent are used as explanatory factors for protest mobilization (Gurr 1970; Opp 1988). The second line of thought has been relatively less studied since the second half of the twentieth century. Emergence of the new social movement theory has led to the generally accepted idea that economic growth and wealth accumulation foster the rise of protests addressing non-material issues. Since the period of economic growth abruptly ended, protests addressing socio-economic inequality and redistribution have been on the rise (Giugni and Grasso 2016). As theories relying on the role of resources do not offer a comprehensive explanation for protest participation in times of hardship (Galais and Lorenzini 2017) arguments based on grievances are becoming relevant once again with researchers aiming to discover to what extent the economic hardship inflicted on citizens upon the implementation of austerity measures post-2008 has increased protest participation.

The respective relevance of these theories, as well as their interaction, has been tested by analysing the genesis and background of social responses to the economic crisis. However, the knowledge obtained is based almost exclusively on case studies of countries of southern Eurozone periphery. They tested the aforementioned theories empirically but have not reached a conclusive answer, showing that different patterns were observed in specific national contexts (Rüdig and Karyotis 2014; Flesher Fominaya 2014; Muñoz et al. 2014; Anduiza et al. 2014; Accornero and Pinto 2015; Giugni and Grasso 2016; Portos 2017; Della Porta et 
al. 2017; Galais and Lorenzini 2017; Altiparmakis and Lorenzini 2018). Similar processes in other European countries have been neglected. The post-socialist countries of Central and Eastern Europe, which are, to a different degree, integrated into the EU and, therefore, prone to spill over effects, both of crisis itself and its political effects, have been almost completely left out from the literature (Beissinger and Sasse 2014).

The contextual characteristics provide one possible explanation for the cross-national variations in protest participation. Each country has distinctive institutional structures and practices shaping people's attitudes and behaviour. In social movement literature, the political opportunity theory departs from the same point. National institutions' specificities are used to explain the emergence, form, level, and decline of protests (McAdam 1986; Tarrow 1989; Kriesi et al. 1995; Kriesi 2004; Tilly and Tarrow 2006). Koopmans (1996) argued that openness of state to citizens' demands determines the costs of participation and the success of collective action. If the state is open towards its citizens, the costs are lower and the chances that collective action will be successful rise. Consequently, if the state is more open towards demands, citizens will be more willing to participate more, as they have opportunities to fulfil their interests (Quaranta 2016). The economic crisis and the democratic crisis it fuelled (Della Porta 2017) can be seen as an opening in the political opportunity structure which enables engagement in collective action (McAdam et al. 1996).

Recent comparative studies claim that the state of the economy - measured as GDP growth, unemployment rate, and inflation rate - can serve as a predictor for the number of crisis related protests in a given country (Vassallo and Ding 2016). Beissinger and Sasse (2014) argue that variables such as GDP growth and GDP per capita are negatively associated with the number of protests. Unemployment and inflation rates are positively associated with protest, as the loss of a job, for instance, brings out strong grievances in citizens (Hooghe 2012; Kern et al. 2015). Although studies show that macro-economic factors obviously have an effect on protest participation, the moderating role of pre-existing institutional arrangements, such as the type of welfare state, remains understudied.

The crisis has produced major economic contractions and, above all, a decline in economic growth and an increase in unemployment rates (Grasso and Giugni 2016). Initial responses to the crisis were interventionist fiscal measures. From 2009, with the emergence of the Greek debt crisis, European institutions started to impose a set of austerity policies to its member states. Armingeon and Baccaro give a good overview of that process:

"Governments of different political orientations, of different political strength and with different capabilities for concertation with the social partners found themselves implementing essentially the same structural adjustment program centred on public sector cuts, pension reform, easing of employment protection legislation, wakening of unemployment insurance, and flexibilization of collective bargaining" (2012: 182, in: Della Porta et al. 2017: 10).

These policy changes had an immediate effect on citizens' lives whose socio-economic situation degraded even further as policies targeted the core of the welfare state: unemployment benefits, pension systems, and labour legislation (Cinalli and Giugni 2016). The pre-existing welfare arrangements changed, but citizens continued to ex- 
pect the same (if not increased) level of social protection from the newly emerged economic uncertainty (Hemerijck 2013). Austerity measures lead to lower growth, higher unemployment, withered infrastructure, and more skewed distribution of income and life chances (Blyth 2013: 28).

The vested welfare arrangements are hard to change as they are the outcomes of previously articulated organized interests and electoral preferences. In times of crisis, the welfare state faces trade-offs: resources are limited, and it has to be decided whose risks to prioritize (Pierson 1996; Hemerijck 2013). Specific welfare arrangements have tremendous consequences for individuals and specific socio-economic groups. Notably, past and current welfare preferences and expenditure levels limit alternative policymaking (Brooks and Manza 2007). They also shape citizens' preferences towards possible changes in existing social programmes (Pierson 1996). Institutions can influence individual behaviour because individuals form their opinion within particular institutional contexts of an already existing welfare state (Esping-Andersen 1990). If welfare states shape individual behaviour, they can serve as a predictor for participation because "welfare states distribute and redistribute resources which enhance the chances average citizens have to participate in political protest (Quaranta 2016: 72)".

Regardless of the predictors that can explain the changes in levels of protest participation, it should be noted that collective actions form an inextricable part of politics in both prosperous times and in times of crisis. However, perhaps it is plausible to assume that, due to the influence of the aforementioned predictors, the character of protest participation will vary. Kerbo (1982) presented six differences between these movements. For movements of crisis to happen, the precondition is found in threatening political and/or socioeconomic crisis, while movements of affluence happen in relatively stable periods. In movements of crisis, participants are oriented towards a specific movement, and they engage in collective action only if they are going to benefit directly from the fulfilment of their demands. In contrast, participants in movements of affluence are typically conscious of the different social issues they tend to address in their collective engagement. In terms of organization, movements of crisis are usually relatively unorganized and spontaneous, while movements of affluence begin with a social movement organization and a clear leadership structure. Due to that, usually in their early stages, movements of crisis tend to use a more violent repertoire and express more hostile outbursts towards authorities, while movements of affluence use a more traditional protest repertoire. Finally, movements of affluence systematically use individual rewards and coercion to promote active participation, while movements of crisis are not able to do so until (and if) they consolidate.

This paper aims to examine the said distinction between movements of crisis, and movements of affluence, their participants, organizational structures and the repertoires they employ within the Croatian context. In the absence of data on protests activity, it was impossible for scientists interested in this topic to empirically test Kerbo's theory. The data collected via PEA represents a ground-breaking opportunity to analyse the features of protest events in Croatia.

\section{Taking Varieties of Capitalism and Welfare State into Account: The Croatian Case}

The damaging effect of the crisis on peripheral Eurozone members has become 
an axiom, but it has not been broadly recognized that it has had an even more disastrous effect on non-member countries that were deeply intertwined with Eurozone members (Bartlett and Prica 2013). At the same time, the picture of the European periphery is not uniform. Despite the general demise of the economy, some post-socialist countries have only stagnated in terms of economic growth or even maintained it positive during the crisis peak, while negative economic trends were recorded in seven countries, Croatia included. ${ }^{9}$

With the memory of the period of deep economic contraction and political turmoil that had happened during the 1990s still very vivid, after 2008 these countries had to confront a new phase of steep economic decline. Therefore, it is important to underline first the severity of the economic recession that hit post-socialist Europe in the early 1990s. The economic situation was alarming already during the last days of socialism (Greskovits 1998). In the transition period it was further exacerbated with the implementation of reforms which were encouraged or pressured by Western governments and international organizations (Fidrmuc 2003) under assumptions that the same type of reform was applicable in all countries (Bohle and Greskovits 2012). Post-socialist countries experienced dramatic contractions of their economies. The transformational recession was unexpectedly severe - cumulatively, output fell by between $15 \%$ in the Czech Republic and $75 \%$ in Georgia (Fidrmuc 2003). In some coun-

9 Bulgaria, Romania, Czech Republic, and Russia stagnated in terms of economic growth, Albania, Belarus, Macedonia, Moldova, Poland, Serbia, and Slovakia managed to maintain it positive during the crisis peak. The negative economic trends were observed in Croatia, Estonia, Hungary, Latvia, Lithuania, Slovenia, and Ukraine (Beissinger and Sasse 2014). tries, economic growth was further limited by military conflicts.

In this context, despite the relatively successful stabilization policies, implemented by governments to tackle hyperinflation and to stabilize the currency, economic recovery was impossible (Stubbs and Zrinščak 2009). With the notable exception of the Visegrad countries $^{10}$, post-socialist countries have had not reached the 1989 levels of GDP in the first decade of the transition (Fidrmuc 2003). Bohle and Greskovits (2012) suggest that the severity of the crisis was somehow expected in the countries that lacked institutional capacities to implement economic reforms. In these cases, governments conducted reforms based on patronage politics and implemented compensatory policies fused with nationalism.

In the second part of 1990 s and in the early 2000s, the perspective of EU membership became the driving force of further administrative, institutional and regulatory reforms aiming to depoliticize policymaking by removing it from the realm of national decision making (Bohle and Greskovits 2012). The prospect of European integration served also as a justification for unpopular decisions. It legitimised neoliberal policies that were supposed to lead to monetary stability and fiscal discipline, while promoting welfare state retrenchment. Political parties became nonresponsive to their electorate's preferences, and responsive to supranational institutions while trying to buy social peace, mostly by negotiating with labour unions and employers, promising rapid growth and stability upon EU accession (Bohle and Greskovits 2012).

10 Poland, Hungary, Czech Republic and Slovakia reached the 1989 level of GDP in the second half of the 1990s (Stubbs and Zrinščak 2012). 
The described period of economic hardship, national states' poor capacity to respond to its challenges, and solutions prescribed by the EU mirror the situation that the rest of Europe has seen after the 2008 crisis. However, with one notable distinction - Greskovits (1998) argued that in the 1990s Eastern Europe saw a period of demobilization because economic and political crisis affected the capacity necessary for collective action. Vanhuyse (2006) claimed that despite dramatic increases in poverty and inequality, and against theoretical assumptions, the transition period in post-socialist countries was astonishingly peaceful. His explanation for the deficiency of contentious actions lied in the strategic use and compensatory nature of social policies which pacified considerable portions of the population $^{11}$.

Bohle and Greskovits (2012) claim that Croatia was a capable state when it became independent from Yugoslavia. However, the war and its aftermath, nationalism and Tuđman's regime undermined the state's capacities, and Croatia failed to embrace neo-corporatism in the way Slovenia did. The country could not achieve economic growth, and macroeconomic instabilities were recurring. Posts in the administration, judiciary, and in state-owned enterprises were filled with people loyal to the ruling party regardless of their competences. The privatization of state-owned companies followed the same logic. Social spending was extensive, but narrowly targeted one stratum: war veterans and their families (for details on the compensatory nature of these policies see Begić and al. 2007; Dobrotić 2008; Stubbs and Zrinščak 2009; Dolenec 2017). Demo-

11 His analysis is based on cases of Poland, Hungary and the Czech Republic. Bohle and Greskovits (2012) show that similar conclusions are applicable for the other countries in CEE. graphic renewal was proclaimed to be one of the main governmental goals. Therefore, spending on natality-oriented family policies was substantive as well (for overview of family policy making see Zrinščak and Puljiz 2002; Puljiz 2008). Hrvatska demokratska zajednica $(\mathrm{HDZ})^{12}$ used particular social policies to legitimise its governance. It did not engage in bargaining with the unions in the tripartite arena as these were perceived as potentially strong mobilizers and political opponents. Towards the end of the 1990s, the unions started to behave in that way by challenging the crumbling Tuđman's regime (Bahtijari 2001; Grdešić 2008; Bohle and Greskovits 2012).

During the first decade of the 2000s, Croatia underwent a deep economic and democratic transformation. The 2000 parliamentary elections marked the end of democratic transition as the rule of HDZ ended. A coalition of centre-left parties won the elections (Kasapović 2001; Dolenec 2013; Henjak et al. 2013). Both economic and social indicators improved. However, integration into the global financial market unmasked external vulnerabilities of the economy. Foreign debt was on the rise, and household and corporate debts were in foreign currencies (Franičević 2011; Sanfey 2011). The labour market structure reflected the distinction between workers on permanent contracts (usually employed in public services, protected by collective agreements and labour union membership) and those with temporary contracts, generally working in the grey economy and prone to numerous risks (Franičević 2011).

During the first several of months of 2008, the forecasts were optimistic.

12 Croatian Democratic Union, the main centre-right political party that ruled Croatia from 1990 to 2000 , from 2003 to 2011, and since 2016. 


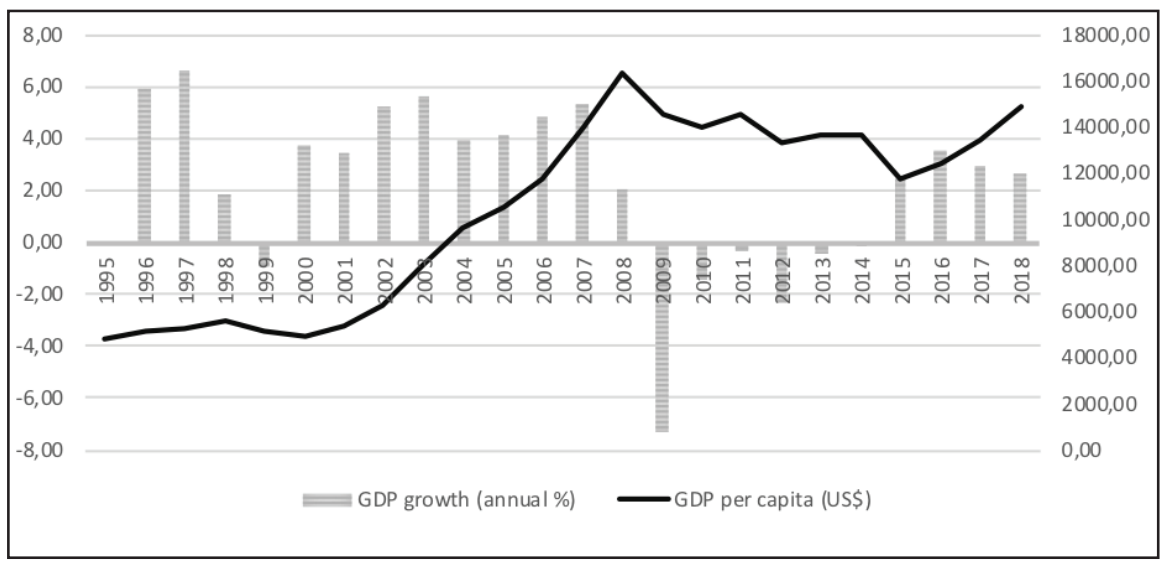

Figure 1. GDP Changes 1995-2018

(source World Bank, adapted by the author)

Macroeconomists thought the crisis would not hit Croatia due to macroeconomic stability, increasing investments, stable political climate and the prospect of full EU membership in sight. GDP per capita reached a peak (see Figure 1). Dramatic change happened in the autumn of 2008, when the significant drop in economic activity became obvious and started impacting other macroeconomic variables. GDP growth rate hit rock bottom in the first quarter of 2009 (Franičević 2011). In terms of societal impacts, the crisis prompted the citizens to renounce the idea that the country was slowly catching up with Western Europe and to accept that post-socialist countries, despite the intended convergent EU policies, had never caught up with old member states (Musić 2013). The country was economically tied to the EU. Additionally, it needed to maintain political and social stability to be able to fulfil the strict pre-accession criteria. Thus, any policy making aiming to tackle the crisis was profoundly limited by recommendations from European institutions.

None of the recommendations helped the economy recover. As seen in Figure
1, GDP growth was negative for 6 consecutive years, from 2009 to 2014 . The first signs of recovery were recorded as late as 2015. GDP per capita, in spite of gradual growth since 2015 onwards, has still not reached the 2008 level. These indicators demonstrate that Croatia went through a period of deep and lasting economic crisis which led to a deterioration of living conditions, and, as a consequence, impacted patterns of protest participation (Della Porta 2017). Taking the said into consideration, one should wonder how the decade of economic downfall affected protest participation in Croatia.

Against the backdrop of this political-economic context, the next section offers an analysis of protest activity in the period 2000 to 2017 . One should assume that grievances which grew during the crisis would be articulated through protests. However, the national institutions' specificities and traditions are used to explain various protest features (McAdam 1986; Tarrow 1989; Kriesi et al. 1995; Kriesi 2004; Tilly and Tarrow 2006). Existing welfare arrangements are hard to change since they represent outcomes of previously articulated or- 
ganized interests and electoral preferences. In times of crisis resources are limited, and it has to be decided whose risks should be prioritized (Pierson 1996; Hemerijck 2013). Croatian social policy making is described as "captured" (Stubbs and Zrinščak 2009) and "compensatory" (Begić and al. 2007; Dobrotić 2008; Stubbs and Zrinščak 2009; Dolenec 2017), the mobilizing role of labour unions as moderate (Grdešić 2008), and a large share of the population as relying on clientelistic relations with the state (Bohle and Greskovits 2012). Thus, it could have been expected that Croatians would behave in the same way that Vanhuyse's (2006) analysis suggests - no matter how harsh the austerity measures, a significant share of the population would remain pacified as long as there is no change in existing welfare arrangements. If challengers of the status quo appeared, they should be younger people with temporary contracts, employed mostly in the grey economy and prone to numerous risks (Franičević 2011) who are willing to raise awareness that not everyone in the society bears the consequences of economic hardship equally (Giugni and Grasso 2016). However, as a large proportion of the younger unemployed cohort emigrated from Croatia with the first signs of economic decline (Župarić-Iljić 2016), this probably affected the levels of protest activities, making them significantly lower than in other European countries. ${ }^{13}$

Additionally, as the observed period encompasses both periods of economic growth and periods of economic crisis, this enables us to analyse Kerbo's theses about the characteristics of protest activities in periods of crisis and periods of affluence (Kerbo 1982). It is expected that

13 See O'Connor in Della Porta (2017) on the effects of emigration for the austerity related protest in Ireland, and Bohle and Greskovits (2012) in Baltic countries, Hungary and Poland. in movements of crisis, people are more engaged in unorganized and spontaneous collective action, and that they participate only if they directly benefit from the action, without having a tendency to actively participate in the movement for a longer period. They would also be more likely to resort to a more violent repertoire and express more hostile outbursts towards the authorities.

\section{Results and Discussion}

Given that the newly collected data that has never before been available for Croatia is presented here, before exploring the main thesis of this paper we shall look into the main trends in the given period. Although there is no consensus on the most efficient way to measure changes in protest actions, two variables have been used: the number of events and the number of participants in all recorded protest events (Beissinger and Sasse 2014; Biggs 2018). ${ }^{14}$ Early studies assumed a high positive correlation between the frequency of protest events and the total number of participants. However, these studies show that correlation is, in fact, low or, at best, moderate, meaning that the choice between counting events and counting participants will drastically affect the prospective conclusions (Biggs 2018). Overall 2,806 protests and 1,713,435 participants ${ }^{15}$ were recorded in Croatia

14 Beissinger and Sasse in their analysis use a third variable, the total number of protest days. This measure is more useful for comparative studies, and therefore is not used in the presented analysis.

15 Ekiert and Kubik (1998) showed that the main problem for scholars using PEA data is the high frequency of missing values for the "number of participants" variable. The same is applicable here: In 1010 cases, or $37 \%$ of all recorded events, the exact number of participants was not reported. An additional obstacle to acquiring the most possibly accurate total number of participants lies in the nature of reporting. The 
in the covered period. The number of participants in the observed period means that on average $2.2 \%$ of the population was mobilised in different protest activities. The PEA dataset enables us to compare this level of mobilization to those observed in Serbian, Spanish and Portuguese cases. As national censuses were conducted in all four countries in 2011, the size of the population from the census data was used for weighting. ${ }^{16}$ In both Croatia and Serbia, around 2\% of the total population participated in protest events over the entire observed period, both before and after $2008 .{ }^{17}$ In Portugal and Spain, the average level of participation is higher, $7.63 \%$ and $8.22 \%$ respectively. ${ }^{18}$

newspapers customarily report estimates delivered by the organizers, the police (or other authorities) and the reporters. These numbers often vary significantly and sometimes reflect a tendency of the organizers to inflate the numbers and of the authorities to diminish the credibility of the stated demands by lowering the numbers. Sometimes the reported estimates mirror editorial politics. Coders were instructed to gather all reported numbers. The most conservative estimate was used for the analysis.

${ }_{16}$ The recorded population in Croatia was $4,284,889$ people, in Portugal 10,562,178, in Serbia 7,186,862, and in Spain 46,815,916.

172000 and 2001 represent outliers in the Serbian case - almost $30 \%$ of citizens participated in two general strikes and protests related to October 5 (Dolenec et al. 2019).

18 In Portugal and Spain, mobilization levels seem to correspond to particular cycles of contention. The highest level of mobilization in Portugal, 33\% of population, was recorded during the first wave of anti-austerity protests. In Spain, it surpassed $20 \%$ of the total population only in 2003 and 2004 during protests against the war in Iraq, and in the aftermath of the terrorist attack in Madrid. The anti-austerity protest cycle managed to maintain the level of mobilization over 5\% for four consecutive years, reaching its peak in 2013. In the post-crisis period, the level of mobilization in Portugal dropped below the one in Croatia and Serbia. In 2017 all countries, apart from
Figure 2 shows that the highest number of protests was recorded in 2000 and 2001. Strikes represent the largest share of recorded protest events in these two years. This period was deeply marked by workers' mobilizations and dissatisfaction with the consequences of the political and economic changes in the 1990s. Due to data limitations it is difficult to assess if they represent a continuation of mobilizations from the late 1990s (Grdešić 2008), though protestors' demands show that their nature is unaltered. They demand a revision of the privatization processes and payment of unpaid wages and/or severance pay, while simultaneously examining the role of previous and incumbent governments in shielding those responsible for criminal activities during the period of privatization. At the same time, veterans' associations organised numerous multi-local demonstrations to condemn the government's cooperation with the Hague Tribunal.

Starting from 2003, economic and social indicators started to improve, and political parties, employers, labour unions and civil society came to a consensus that achieving European integration should be the main priority. The relative economic and social stability was reflected in the decline of protest activities. From 2003 to 2007 a rather invariable trend in both the number of events and participants is observed. The high number of participants in 2004 represents the only outlier but can mostly be explained by a several days' long strike in public services. ${ }^{19}$ The same can be

Spain, recorded low levels of mobilization. The level of mobilization in Spain has risen again, mainly due to the Catalan independence movement (Dolenec et al. 2019).

19 As official reports on the numbers of strikers are non-existent in Croatia, media outlets usually report numbers provided by unions. There is a possibility that the numbers have been inflated by the organizers. 


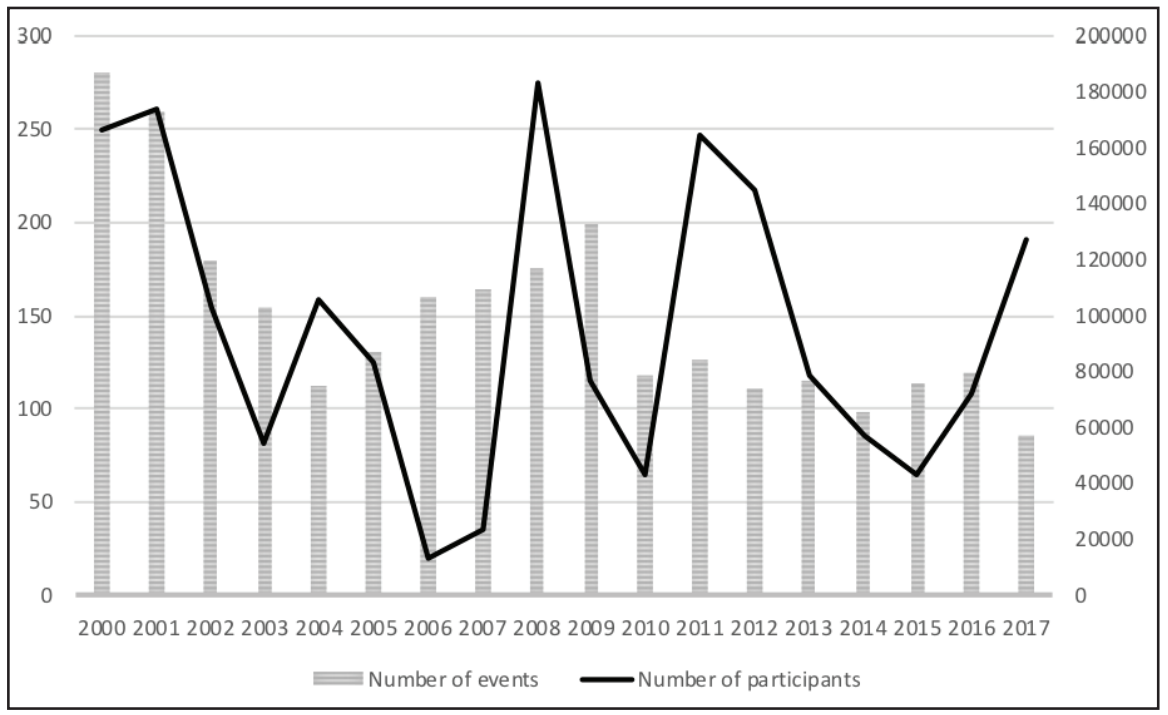

Figure 2. Number of protest events and participants in Croatia, 2000-2017

said of the number of participants in 2008 which represents the highest annual number of protest participants in the dataset. The labour unions of public sector employees organized a massive protest in Zagreb demanding a "radical change in economic and social policies" that was attended by more than 50,000 participants. This finding is in line with the existing notion in literature which claims that strikes tend to be more frequent when economies are expanding rather than contracting. In tough times workers' jobs are at the mercy of employers, and workers have greater difficulty withholding labour when their jobs are under threat (Tilly and Shorter 1974; Hibbs 1976, as quoted in: Beissinger and Sasse 2014).

The year 2011 marked the beginning of protests organized by citizen initiatives which could be regarded as anti-aus-

The implications for analysis are obvious - In years when multi-sector, multi-day or general strikes are recorded, an overestimated number of participants is plausible. terity protests similar to those in Spain and Portugal. This period is described in depth later in the paper. In 2012 and 2013 ideological divisions between the progressive left and the traditional right became prominent and mobilized over 100,000 people during that period. The final rise in the number of participants reflects two large protests advocating for school curriculum reform: one in 2016, and the second one in 2017.

In the observed period, protests addressing demands related to economic protest represented a large share of all reported events. In this analysis, economic protest refers to protests where participants formulated one or more demands regarding cuts to public services, austerity, inequality, unemployment, dismissals, redundancy procedures, salary cuts, precarity, debt, housing crisis and price increase. ${ }^{20}$ Although they

20 Demands for analysis were selected based on definition of austerity measures Leventi et al. (2010) provided. As austerity measures/ policies in some countries represent explicit 


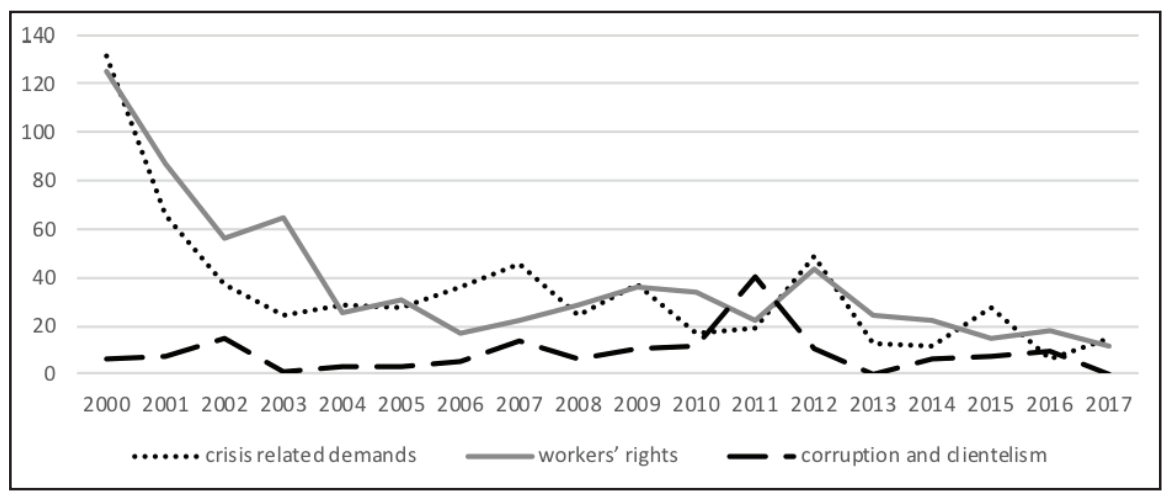

Figure 3. Crisis related demands vs. other demands

also represent materialistic demands of sorts, workers' rights related demands have been included in the analysis but separately according to the logic that they represent the "old" type of labour contention as opposed to newer crisis related demands (Dolenec et al. 2019).

From Figure 3 it can be observed that both types of demands were primarily represented in the dataset in the early 2000s. They remained important during the rest of the observed period, peaking in 2012. Figure 3 also shows the number of protests where demands against corruption and clientelism were articulated. Presence of these demands in the early 2000 s can be related to the ques-

packages of reforms, while in others, they cannot be identified as whole packages, it is necessary to list policy changes which can be defined as austerity measures: "... [they] take the form of some combination of: (i) reductions in cash benefits (and public pensions); (ii) increases in direct taxes and contributions; (iii) increases in indirect taxes; (iv) reductions in public services that have an indirect impact on the welfare of households using them; (v) reductions in public expenditure that cannot be allocated to households (e.g. pure public goods like defence spending) and increases in taxes that are not straightforward to allocate to households; (vi) cuts in public sector pay (vii) cuts in public sector employment (Leventi et al. 2010: 7). tioning of the role of political elites in the period of privatization. Later in that period, they reflect growing distrust in the government and other institutions.

In 2009 the government introduced new taxation, raised the rate of value-added tax, cut spending in ministries and state companies, and revoked free transportation and textbooks for pupils (Franičević 2011). Labour unions led protests against these measures, highlighting that they were immoral and inadequate responses to the economic situation. At the same time, workers and farmers rebelled against the state's tendency to halt subsidies and to privatize the last remaining state-owned companies. All these protests reflect the high number of economic protest and workers' rights protests in 2009 as seen in Figure 3. Workers' protests became predominant once again in 2012, with strikes in textile and metal industries. Public employees held a one-day strike with over 70,000 people participating. Although protest activities organized by labour unions were visible during the crisis, they were relatively low when compared to the beginning of the 2000s. The data shows that the level of mobilization due to workers' rights and eco- 
nomic protests has been in decline ever since.

The 2009 student movement addressed problems of commercialization of higher education (Dolenec and Doolan 2013). Students occupied the universities, and organized marches and sit-ins where they were joined by other citizens: parents, workers, professors, and activists. The government seemed to be aware of the mobilization potential the students had. Balković (2014) showed that Croatians prioritized governmental spending on public education over other types of social spending. If citizens assumed that cuts were going to affect the part of welfare state which they cared most about, they would be likely to engage in contentious actions to defend the existing arrangements. Thus, it can be said that the government wanted to prevent student protests from spreading to broader social groups whose discontent would be triggered by cuts in the sector that everyone benefited from once during their lifetime. By fulfilling the most important student demands, the government used a very well documented tactic to pacify a rebellious portion of society, and possibly prevented bursts of broader dissatisfaction. The main slogans the movement was using were "One World, One Struggle" and "Knowledge is not a Commodity" which related specific problems within Croatian higher education with universal topics such as lack of "real" democracy, inequality of chances, and corruption of the dominant neoliberal system. Štiks and Horvat (2014) see this movement as the first political opposition to governmental policies, but also to the dominant political, economic, and social regime. Insights from PEA data about the nature of the movement confirm Štiks and Horvat's (2014) argument that it could be interpreted as an anti-austerity one.
From 2009 to 2011 "The Right to the City" movement opposed a developmental project in downtown Zagreb. Protestors used the most diverse repertoire of action that social movements in Croatia had used ever before, ranging from demonstrations, occupations, sitins to symbolic and theatrical performances. Dolenec et al. (2017) note that this broad range of action repertoire, especially public space occupation, predates similar strategies used in the Indignados protests and in the "Occupy" movements. As student protests, the movement managed to relate particular problems concerning the protection of urban space with universal topics such as political unresponsiveness, violated democratic practices, and opposition to neoliberalism (Dolenec, Kralj and Balković 2019). Additionally, the movement represented an important instance of cooperation between environmental organizations, organizations from the independent cultural scene, student organizations, unions, workers and grassroots initiatives whose cooperation has evolved and grown in capacity since 2000 (Dolenec et al. 2017), eventually leading to the establishment of a political party called "Zagreb je naš" (Zagreb is Ours). The party formed a coalition with smaller left-wing parties and competed in mayoral and city assembly elections managing to gain 4 seats in the City Assembly only 3 months following its formation (Dolenec, Kralj and Balković 2019).

The year 2011 marked the beginning of protests organized by citizen initiatives which share some features of anti-austerity protests that occurred in Spain or Portugal. The government had passed a harsh programme of economic recovery in 2010. However, the 2011 wave of discontent started only with protests of war veterans, rightist organizations and football fans against the 
government and its policies - including those aimed at tackling the effects of the crisis. Their demands were not communicated clearly, and it seemed as if they were only questioning the HDZ government's capacity to govern. Dolenec and Širinić (2020, forthcoming) showed that when HDZ is in the office, veterans cooperate with the state and mobilize only to strengthen its legitimacy and weaken the opposition. In that sense, this mobilization represented a departure from known protest patterns. These protests were an introduction to a sequence of events organized by the citizen initiative which managed to communicate their grievances in a more comprehensive way. Because they were the first to rely on Facebook to mobilize people, the protests became known as the Facebook protests. In months to follow they organized fourteen marches through $\mathrm{Za}$ greb, as well as demonstrations in various cities. Although the Facebook group had almost 50,000 members, the number of citizens who attended marches and related events varied significantly on a daily basis. The highest recorded number of participants - over 20,000 of them - was recorded during the protest held on March $5^{\text {th }}$.

In their marches, the protesters went visiting governmental institutions, headquarters of the main political parties, and banks, but also politicians' homes where they would either bang pots or just shout to disturb members of politicians' households - both strategies that were also used in the Spanish anti-austerity protests. PEA data provides no grounds for conclusions on who the participants were. Media reports mainly labelled them as "unsatisfied citizens". It is however clear that an extremely diverse group of citizens protested. Their allies kept changing from one march to another. Some marches were supported by the biggest labour unions, while in some others labour unions were the direct target of the protest, blamed for treason for collaborating with the government. Protesters addressed the economic and the social situation, expressing distrust in media, and national and supra-national institutions while indicating dissatisfaction with the dominant capitalist system and social inequality it produces. As predicted, they were protesting against the high levels of corruption and clientelism. There were calls for the restoration of "moral principles" and "traditional values". The same "lovehate" relationship that the protesters had with the labour unions, they had with the Catholic Church. On several occasions they expressed distrust in the Church, while on other occasions the leftist participants had quarrels with the right-wing ones over the presence of religious symbols. The general anti-EU feeling was omnipresent, but again, different views were clashing: some participants were strongly against Croatia entering the EU, while others were pro-EU but did not agree with the solutions that the EU offered during the crisis. The initiative did not have a clear organizational structure, though some individuals tried to position themselves as leaders. However, the participants did not support that endeavour, so nobody officially directed the future course of action. That led to a gradual disintegration of protests. In the years following these protests some of the actors involved in their organization became prominent political actors.

Already that same April, the initiator of the protests, Ivan Pernar, established a political party - at the time called $\mathrm{Al}$ liance for Change (Savez za promjene) and announced that it would participate in the upcoming parliamentary election. Elections were held in December 2011. Pernar's party did not achieve any success. However, its popularity gradu- 
ally started to rise due to the party activists' well-mediatized participation in anti-eviction activism which led to the party's rebranding as Human Shield (Živi zid) in August 2014. In spite of unfavourable economic conditions, bigger protests related to the economic grievances. Rather it can be said that the period of post-materialist, new social movements (Della Porta 2015) had begun. In 2012 and 2013 ideological divisions between the progressive left and the traditional right became very prominent, and topics such as same-sex marriage, the Concordat with the Vatican, minority rights, and politics of memory dominated the public sphere. The protest arena was no longer used dominantly by actors from the left. Organizations such as In the Name of the Family (U ime obitelji), numerous veteran organizations, and Circle for the Square (Krug za trg) were leading the mobilization on the right. The same trend continued in 2014 and 2015, with war veteran acampada on the premises of the Ministry of Veterans Affairs. It lasted for 555 days, becoming the longest protest recorded in recent Croatian history. Veterans demanded the resignation of the Minister, as well as an expansion of their benefits because the social democratic government tried to cut the existing ones. As both presidential and parliamentary elections were held during the acampa$d a$, the protestors openly favoured HDZ candidates. They withdrew from the Ministry's premises only after the HDZ won the 2015 parliamentary election.

These presidential and parliamentary elections were marked by unforeseen success of the Human Shield. One of their most renowned activists, Ivan Vilibor Sinčić, had announced he would run for president. Despite entering the race as an underdog, he placed third in the first round. This venture and the anti-eviction activities led to nation- al recognition for the party which was reflected in the 2015 election. The party secured one parliamentary seat. In the 2016 snap election, the Human Shield formed a coalition with several other actors and won 8 seats. The success signalized that the party had become a relevant political actor that had undergone transformation from an activist organization to a political party. In that sense it can be regarded as one of the new parties - such as Podemos in Spain - that have emerged after the crisis and disrupted the existing party system by taking a significant portion of voters from multiple parties.

\section{Conclusion}

Due to a lack of data, neither the Croatian cycle of anti-austerity protests nor protest dynamics in general have been studied systematically. Using original data, this paper aimed to explore if an austerity-fuelled cycle of contention did occur in Croatia.

By giving an overview of protest activities in Croatia in the last two decades, it showed that national varieties of capitalism influenced patterns of protest participation in a given country. The dynamics of contention in Croatia has been influenced by long-term effects of the so-called 'transition period' from the early 1990s. The opportunity to challenge the existing political alignments during the short period of economic growth and political stability in the early 2000s did not arise. The findings from PEA data are in line with theories claiming that the national institutions specificities serve as predictors of protest dynamics. The analysis confirmed Vanhuyse's (2006) findings: a large proportion of the population remained pacified throughout these 18 years due to captured and compensatory social policy making. Broad social groups, such as veterans, rely on clientelist relations with 
the state, and protest only when they feel their benefits are endangered, usually when social democrats are in power. At the same time, the beginning of the 2000s was marked by workers' mobilizations and dissatisfaction with the consequences of the political and economic changes in the 1990s. Only later in the 2000 s, in times of relative economic stability, did the labour unions advocate for better working conditions and start questioning policy changes. That being said, workers' protests can be seen as the only outlier in the usually obedient protest arena in the first part of the 2000s.

Second, based on our knowledge of the protests in the 1990s and in the years preceding the crisis, it could have been be assumed that no matter how harsh the austerity measures, a significant share of the population would remain pacified as long as there is no change in existing welfare arrangements. Nevertheless, in the aftermath of the 2008 crisis challengers of the status quo did appear and it can be said that the post-2008 wave of contention in Croatia does exist. The analysis showed that protests directly addressing austerity measures have indeed taken place, starting with the student protests, and culminating with the Facebook protests in 2011. The student protests and "The Right to the City" movement managed to connect specific grievances with universal ones. They addressed the democratic deficit and corrupt dominant neoliberal system and the social inequalities it accentuates and perpetuates. They preceded the Facebook protests in formulating and expressing socio-economic grievances and articulated an anti-systemic sentiment by criticizing neoliberalism and austerity. Due to their strong organizational structure and abundance of resources in terms of participation and activists' "know-how", these movements resemble Kerbo's (1982) movements of affluence. On the other hand, the Facebook protests lacked organizational structure and continuous engagement. They were motivated mainly by the general dissatisfaction with corrupted elites and a sense of not being represented. In that sense, they can be seen as corresponding to Kerbo's (1982) movements of crisis. That common feeling of dissatisfaction brought together people of different ideological backgrounds, which prevented the movement's persistence and more cohesive demands making. Additionally, the Facebook protests lacked resources and organizations which would help them to articulate grievances. However, the protests have left an important mark on the Croatian political system - they had helped some of their initiators to establish an anti-system political party that would gain significant electoral success in just a few years' time.

In a nutshell, the post-2008 wave of contention was not only fuelled by the crisis and the austerity measures that ensued, but also by socio-economic grievances that had accumulated in preceding periods, but which were omitted from the political mainstream due to the lack of actors and possibilities to represent them. Any further analysis would need to address the content and intentions of the proposed and implemented austerity policies and connect these with particular protest events recorded in the PEA dataset. This would enable exhaustive process tracing and give provide a deeper understanding of the nature of this cycle of contention. 


\section{References}

Accornero, Guya, Ramos Pinto, Pedro. 2015. "Mild Mannered"? Protest and Mobilization in Portugal under Austerity, 2010-2013. West European Politics. (38) 3: 491-515.

Almond, Gabriel A., Verba, Sidney. 1963. The civic culture. Princeton: Princeton University Press.

Altiparmakis, Argyrios, Lorenzini, Jasmine. 2018. Disclaiming national representatives: Protest waves in Southern Europe during the crisis. Party Politics. (24) 1: 78-89.

Anduiza Eva, Cristancho Camilo, Sabucedo José M. 2014. Mobilization through online social networks: the political protest of the indignados in Spain. Information, Communication and Society. (17) 6: 750-764.

Armingeon Klaus, Bacarro Lucio. 2012. The Sorrows of Young Euro: The Sovereign Debt Crisis in Ireland and Southern Europe. In: Bermeo, Nancy, Pontusson, Jonas. (eds.) Coping with Crisis. Government Reactions to the Great Recession. New York: Russell Sage Foundation, pp. 162-198.

Bahtijari, Hašim. 2001. Croatia: Workers Save Their Companies Through Strikes and Protests. South East Europe Review for Labor and Social Affairs. (4) 1:21-29.

Balković, Ana. 2014. Public opinion on public education spending in Croatia. MA thesis. Budapest: Central European University. Unpublished.

Bartlett, Will, Prica, Ivana. 2013. The Deepening Crisis in the European Super-periphery. Journal of Balkan and Near Eastern Studies. (15) 4: 367-382.

Begić, Nada, Sanader, Mirjana, Žunec, Ozren. 2007. Ratni veterani u Starom Rimu i u današnjoj Hrvatskoj. Polemos. (10) 20: 11-30.
Beissinger, Mark, Sasse, Gwendolyn. 2014. "An End to Patience?"- In: Bermeo, Nancy, Bartels, Larry M. (eds.). Mass Politics in Tough Times. New York: Oxford University Press. pp. 334-370.

Bermeo Nancy, Bartels, Larry M. (eds.). 2014. Mass Politics in Tough Times, New York: Oxford University Press.

Biggs, Martin. 2018. Size Matters: Quantifying Protest by Counting Participants. Sociological Methods \& Research. (47) 3: 351-383.

Blyth, Mark. 2013. Austerity. The History of a Dangerous Idea. New York: Oxford University Press.

Bohle, Dorothee, Greskovits, Bela. 2012. Capitalist diversity on Europe's periphery. Ithaca and London: Cornell University Press.

Brady, Henry, Verba, Sidney, Schlozman, Kay L. 1995. Beyond SES: A Resource Model of Political Participation. American Political Science Review. (89) 2: 271-294.

Brooks, Clem, Manza, Jeff. 2007. Why Welfare States Persist: The Importance of Public Opinion in Democracies. Chicago: University of Chicago Press.

Cinalli, Manlio, Giugni, Marco. 2016. Collective Responses to the Economic Crisis in the Public Domain: Myth or Reality? Politics \& Policy. (44) 3: $427-$ 446.

Cisar Ondrej, Navratil, Jiri. 2016. Polanyi, political-economic opportunity structure and protest: capitalism and contention in the post-communist Czech Republic. Social Movement Studies. DOI: 10.1080/14742837.2016.1235497

Dalton, Russell J. 1988. Citizen Politics in Western Democracies. Public Opinion and Political Parties in the United States, Great Britain, West Germany, and France. Chatham: Chatham House. 
Dalton, Russell J. 2008. Citizenship norms and the expansion of political participation. Political Studies. (56) 75-98.

Della Porta, Donatella. 2015. Social Movements in Times of Austerity: Bringing Capitalism Back into Protest Analysis. Cambridge: Polity Press.

Della Porta, Donatella et al. 2017. Late Neoliberalism and its Discontents in the Economic Crisis. DOI: 10.1007/978-3319-35080-6

Dobrotić, Ivana. 2008. Sustav skrbi za branitelje iz Domovinskog rata. Revija za socijalnu politiku. (15) 1: 57-83.

Dolenec, Danijela. 2013. Democratic Institutions and Authoritarian rule in Southeast Europe. Colchester: ECPR Press.

Dolenec, Danijela. 2017. A Soldier's State? Veterans and the Welfare Regime in Croatia. Anali Hrvatskog politološkog društva. (14) 1: 55-77.

Dolenec, Danijela, Balković, Ana, Kralj, Karlo, Širinić, Daniela. 2019. Croatia - Protest Event Analysis Dataset, Version 2.0. Centre for Empirical Political Research, Faculty of Political Science, University of Zagreb.

Dolenec, Danijela, Balković, Ana, Kralj, Karlo, Širinić, Daniela, Romanos, Eduardo, Fernandes, Tiago. 2019. Advancing Democracy Through Protest in the South and East of Europe. Paper presented at CES conference in Madrid, June 2019.

Dolenec, Danijela, Doolan, Karin. 2013. Reclaiming the role of higher education in Croatia: Dominant and Oppositional Framings. In: Zgaga, Pavel, Teichler, Urlich, Brennan, John. (eds.). The globalisation challenge for European Higher Education. Convergence and diversity, centres and peripheries. Frankfurt: Peter Lang, pp. 225-346.

Dolenec, Danijela, Doolan, Karin, Tomašević, Tomislav. 2017. Contesting
Neoliberal Urbanism on the European Semi-periphery: The Right to the City Movement in Croatia, Europe-Asia Studies. (69) 9: 1401-1429. DOI: 10.1080/09668136.2017.1385726

Dolenec, Danijela, Kralj, Karlo, Balković, Ana. 2019. Whose Right to the City: Urban Struggles in Croatia and Serbia. Paper presented at ESA conference in Manchester, August 2019.

Dolenec, Danijela, Širinić, Daniela. 2020. (forthcoming). Party-led Mobilization: Veterans as a Pivotal Political Actor.

Earl, J. Andrew Martin, McCarthy, John D., Soule, Sarah A. 2004. The Use of Newspaper Data in the Study of Collective Action. Annual Review of Sociology. (30) 65-80.

Ekiert, Grzegorz, Kubik, Jan. 1998. Collective Protest in Post-communist Poland, 1989 - 1993: A Research Report. Communist and Post-communist Studies. (31) 2: 91-117.

Esping-Andersen, Gosta. 1990. The Three Worlds of Welfare Capitalism. Cambridge: Polity Press.

Flesher Fominaya, Cristina. 2015. Debunking Spontaneity: Spain's 15M/ Indignados as Autonomous Movement. Social Movement Studies. (14) 2: 142-163.

Fidrmuc, Jan. 2003. Economic reform, democracy and growth during post-communist transition. European Journal of Political Economy. (19) 583-604.

Franičević, Vojmir. 2011. Croatia - Prolonged crisis with an uncertain ending. In: Vaughan-Whitehead, Daniel (ed.) Work Inequalities In The Crisis Evidence from Europe. Geneva: Edward Elgar and International Labour Office, pp. 143-197.

Galais, Carol, Lorenzini, Jasmine. 2017. Half a Loaf Is (Not) Better Than None: How Austerity-Related Grievances 
and Emotions Triggered Protests in Spain. Mobilization: An International Quarterly. (22) 1: 77-95. DOI: 10.17813/1086-671X-22-1-77

Giugni, Marco, Grasso, Maria T. (eds.). 2016. Austerity and Protest. Popular Contention in Times of Economic Crisis. London and New York: Routledge.

Grasso, Maria T., Giugni, Marco. 2016. Protest participation and economic crisis: The conditioning role of political opportunities. European Journal of Political Research. (55) 663-680. DOI: 10.1111/1475-6765.12153

Grdešić, Marko. 2008. Mapping the Paths of the Yugoslav Model: Labour Strength and Weakness in Slovenia, Croatia and Serbia. European Journal of Industrial Relations. (14) 2: 133151.

Greskovits, Bela. 1998. The Political Economy of Protest and Patience: East European and Latin American Transformations Compared. Budapest: Central European University Press.

Gurr, Ted R. 1970. Why Men Rebel. Princeton: Princeton Universtiy Press.

Hall, Peter, Soskice, David. (eds.). 2001. Varieties of Capitalism, The Institutional Foundations of Comparative Advantage. New York: Oxford University Press.

Hemerijck, Anton. 2013. Changing Welfare States. Oxford: Oxford University Press.

Henjak, Andrija, Zakošek, Nenad, Čular, Goran. 2013. Croatia. In: Berglund, Sten, Erman, Joakim, Deegan-Krause, Kevin, Knutsen Terje. (eds.). Handbook of Political Change in Eastern Europe. Cheltenham: Edward Elgar, pp. 443-480.

Hooghe, Marc. 2012. Taking to the Streets. Economic Crises and Youth Protest in Europe. Harvard International Review. (34) 2: 34-38.
Horvat, Srećko, Štiks, Igor. 2014. Welcome to the Desert of Post-Socialism: Radical Politics After Yugoslavia. London and New York: Verso.

Hutter, Swen. 2014. Protest Event Analysis and Its Offspring. In: Donatella della Porta. (ed.). Methodological Practices in Social Movement Research. Oxford: Oxford University Press.

Kasapović, Mirjana. 2001. Demokratska konsolidacija i izborna politika u $\mathrm{Hr}$ vatskoj. In: Kasapović, Mirjana. (ed.). Hrvatska politika 1990-2000. Zagreb, Fakultet političkih znanosti.

Kerbo, Harold R. 1982. Movements of "Crisis" and Movements of "Affluence". A Critique of Deprivation and Resource Mobilization Theories. Journal of Conflict Resolution. (26) 4: 645-663.

Kern, Anna, Marien, Sofie, Hooghe, Marc. 2015. Economic crisis and levels of political participation in Europe (2002-2010): The role of resources and grievances. West European Politics. (38) 465-490.

Kitschelt, Herbert P. 1986. Political opportunity structures and political protest: anti-nuclear movements in four democracies. British Journal of Political Science. (16) 1: 57-86.

Koopmans, Ruud. 1996. New social movements and changes in political participation in Western Europe. Western European Politics. (19) 1: 28-50.

Koopmans, Ruud, Dieter Rucht. 2002. Protest Event Analysis. In: Klandermans, Bert, Staggenborg, Suzanne. (eds.). Methods of Social Movement Research. Minneapolis and London: University of Minnesota Press, pp. 231-259.

Kriesi, Hanspeter, Koopmans, Ruud, Duyvendak, Jan Willem, Giugni, Marco. 1995. New Social Movements in Western Europe: A Comparative Analysis. Minneapolis: University of Minnesota Press. 
Kriesi, Hanspeter. 2004. Political Context and Opportunity. In: Snow, David A., Soule, Sarah, A., Kriesi, Hanspeter. (eds.). The Blackwell Companion to Social Movements. Malden: Blackwell, pp. 67-90.

Makarov, Peter, Jasmine Lorenzini, Kriesi Hanspeter. 2016. Constructing an Annotated Corpus for Protest Event Mining. DOI: 10.18653/v1/W16-5613

McAdam, Douglas. 1986. Recruitment to high-risk activism: the case of freedom summer. American Journal of Sociology. (92) 1: 64-90.

Muñoz, Jordi, Rico, Guillem, Anduiza, Eva. 2014. Empowering Cuts? Austerity Policies and Political Involvement in Spain. In Kumlin, Staffan. Stadelmann-Steffen, Isabelle. (eds.). How Welfare States Shape the Democratic Public. Cheltenham: Edward Elgar. pp. 19-40.

Musić, Goran. 2013. Between Facebook and the Picket Line: Street Protests, Labour Strikes and the New Left in the Balkans. Debatte: Journal of Contemporary Central and Eastern Europe. (21) 2-3: 321-335.

Oliver, Pamela E., Gregory M. Maney. 2000. Political processes and local newspaper coverage of protest events: From selection bias to triadic interactions. American Journal of Sociology. (106) 2: 463-505.

Opp, Karl D. 1988. Grievances and participation in social movements. American Sociological Review. (53) 6: 853-864.

Ortiz, David G., Myers, Daniel J., Walls, Eugene N., Diaz, MariaElena D. 2005. Where Do We Stand with Newspaper Data? Mobilization. (10) 3: 397-419.

Pierson, Paul. 1996. The new politics of the welfare state. World Politics. (48) 2: 143-179.

Portos, Martin. 2017. Keeping dissent alive under the Great Recession: no-radicalisation and protest in Spain after the eventful $15 \mathrm{M}$ /indignados campaign. Acta Politica. (54) DOI: 10.1057/s41269-017-0074-9

Puljiz, Vlado. (ed.) 2008. Socijalna politika Hrvatske. Zagreb: Pravni fakultet Sveučilišta u Zagrebu.

Rüdig, Wolfgang, Karyotis, Georgios. 2013. Who protests in Greece? Mass opposition to austerity. British Journal of Political Science. (44) 3: 487-513. DOI: $10.1017 /$ S0007123413000112

Quaranta, Mario. 2016. Political Protest in Western Europe. Exploring the Role of Context in Political Action. DOI: 10.1007/978-3-319-22162-5

Sanfey Peter. 2011. South-eastern Europe: lessons learned from the global economic crisis in 2008-2010. Southeast European and Black Sea Studies. (11) 2: 97-115.

Stubbs, Paul, Zrinščak, Siniša. 2009. Croatian social policy: The legacies of war, state-building and late Europeanisation. Social Policy and Administration. (43) 2: 121-135.

Tarrow, Sidney. 1989. Democracy and Disorder: Protest and Politics in Italy 1965-1975. Oxford: Oxford University Press.

Tarrow, Sidney. 1993. Cycles of collective action: between moments of madness and the repertoire of contention. Social Science History. (17) 281-307. DOI: $10.2307 / 1171283$

Tarrow, Sidney. 2012. Strangers at the Gates: Movements and States in Contentious Politics. Cambridge: Cambridge University Press.

Tilly, Charles. 2002. Event Catalogs as theories. Sociological theory. (20) 2: 248-54.

Tilly, Charles, Tarrow, Sidney. 2006. Contentious politics. Lanham: Paragon Press. 
Vassallo, Francesca, Ding, Pauline. 2016. Explaining Protest in the Aftermath of the Great Recession in Europe. The Relevance of Different Economic Indicators. Partecipatizione e Conflitto. (9) 1:101-126.

Vanhuysse, Pieter. 2006. Divide and Pacify: Strategic Social Policies and Political Protests in Post-Communist Democracies. Budapest and New York: Central European University Press.

Verba, Sidney, Schlozman, Key L., Brady, Henry E. 1995. Voice and equality: civ- ic voluntarism in American Politics. Cambridge: Harvard University Press.

Verba, Sidney, Nie, Norman H. 1972. Participation in America: political democracy and social equality. New York: Harper and Row.

Zrinščak, Siniša, Puljiz Vlado. 2002. Hrvatska obiteljska politika u europskom kontekstu. Revija za socijalnu politiku. (9) 2: 117-137.

Župarić-Iljić, Drago. 2016. Iseljavanje iz Republike Hrvatske nakon ulaska u Europsku uniju. Zagreb: Friedrich Ebert-Stiftung. 


\section{Val osporavanja potaknut politikom štednje - mit ili stvarnost?}

Sažetak Rijetke su analize prosvjedne dinamike u Hrvatskoj, djelomice zato što se dosad nije mogla analizirati sustavno. Oslanjajući se na nove podatke o prosvjednim događajima od 2000. do 2017, ovaj rad opisuje glavne trendove i dinamiku prosvjednih aktivnosti u Hrvatskoj u tom razdoblju. Rad preispituje tezu Beissingera i Sasse o nepostojanju prosvjeda protiv politike štednje u Hrvatskoj nakon 2008. Unatoč tome što su prosvjedi koji su se izravno ticali politike štednje bili relativno rijetki, ako se uzorak prosvjednih događaja proširi na prosvjede koji su zahtijevali besplatno javno školstvo, zagovarali prava radnika i borili se za pravo na grad, onda je upitan stav o "tišini" u Hrvatskoj. Ovaj rad kani povezati dio prosvjedne dinamike s Kerbovom razlikom između pokretâ u vremenima krize i obilja. Usredotočujući se na razdoblje od studenskih prosvjeda 2008. do Facebook-prosvjeda 2011, rad pokazuje da su studentski pokret i pokret "Pravo na grad" prethodili Facebook-prosvjedima u formuliranju i izražavanju socijalno-ekonomskih zahtjeva te artikuliranju antisistemskih osjećaja. Zahvaljujući snažnoj organizacijskoj strukturi i resursima aktivista, ti su pokreti nalikovali na Kerbove pokrete u vrijeme obilja. Istodobno, Facebook-prosvjedima nedostajali su organizacijska struktura i kontinuirano sudjelovanje građana te odgovaraju pokretima u doba krize.

Ključne riječi Hrvatska, analiza prosvjednih događaja, prosvjedna dinamika, prosvjedi protiv politike štednje 